\title{
WYMIAR SPRAWIEDLIWOŚCI W POLSCE U PROGU 2017 R. - WYZWANIA I ZAGROŻENIA*
}

I. Celem niniejszego artykułu jest przedstawienie najważniejszych zmian i działań na obszarze wymiaru sprawiedliwości projektowanych bądź przeprowadzanych przez rząd Prawa i Sprawiedliwości oraz parlament, w którym partia ta dysponuje większością. Wobec braku możliwości zmiany Konstytucji aktualnie rządząca partia często dokonuje zmian ustrojowych $\mathrm{w}$ drodze uchwalania zwykłych ustaw, łamiąc Konstytucję. W niniejszym opracowaniu chcielibyśmy skoncentrować uwagę na wyzwaniach i zagrożeniach, przed jakimi stoi sądownictwo powszechne.

II. W świetle postanowień obowiąującej Konstytucji Polska jest demokratycznym państwem prawnym, którego ustrój ściśle przestrzega zasady trójpodziału władz, z zachowaniem niezależności władzy sądowniczej oraz z rozbudowanym katalogiem praw i wolności obywatelskich. Wobec braku możliwości zmiany Konstytucji rządząca partia Prawo i Sprawiedliwość postanowiła przeprowadzić zmiany ustrojowe $\mathrm{w}$ drodze uchwalania zwykłych ustaw, nie dbając o ich zgodność z Ustawą zasadniczą. W konsekwencji podstawowym celem partii stało się sparaliżowanie działalności Trybunału Konstytucyjnego ${ }^{1}$. Zmiany w sądownictwie powszechnym w Polsce, które budziłyby wątpliwości konstytucyjne, sa z formalnego puntu widzenia znacznie trudniejsze do przeprowadzenia niż zmiany dotyczące np. prokuratury, a to ze względu na fakt, że postanowienia Konstytucji gwarantują niezależność sądownictwa od władzy wykonawczej i niezawisłość sędziów, realizując zasadę trójpodziału wła$\mathrm{dzy}^{2}$. Okoliczność ta sprawia, że dopóki Trybunał Konstytucyjny pozostawał niezależny od władzy wykonawczej, a jego działanie nie było całkowicie sparaliżowane, gwarancje konstytucyjne dotyczące działalności sądów powszechnych zostały zachowane.

Minister sprawiedliwości-prokurator generalny Zbigniew Ziobro zapowiedział, że zmiany w wymiarze sprawiedliwości zostaną wprowadzone, gdy „,zo-

* Artykuł jest skróconą i zmienioną wersją tekstu przygotowanego dla czeskiego czasopisma „Státní zastupitelství” [,Oskarżyciel Publiczny”] - grudzień 2016 r.; http://www.nsz.cz/index.php/ en/magazine-public-prosecution.

${ }^{1}$ Zob. także: „Ruch Prawniczy, Ekonomiczny i Socjologiczny” 78, 2016, z. 1: H. Suchocka, Stanowisko Komisji Weneckiej dotyczqce pozycji ustrojowej sqdownictwa konstytucyjnego w demokratycznym państwie prawa, s. 5-18; J. Stępień, Rewolucja - świadoma czy nieświadoma, s. 19-33; M. Safjan, Polityka a Trybunat Konstytucyjny. Konstytucja-ostatni środek obrony przed polityka, s. 35-42; A. Zoll, Sposób wyboru sędziów Trybunatu Konstytucyjnego, s. 43-50; W. Łączkowski, Uwagi do aktualnych wydarzeń wokót polskiego Trybunału Konstytucyjnego, s. 51-56.

${ }^{2}$ Zob. także: D. Zawistowski, Niezależność sqdów i niezawistość sędziów z perspektywy prawa Unii Europejskiej, „Ruch Prawniczy, Ekonomiczny i Socjologiczny” 78, 2016, z. 2, s. 7-13. 
stanie rozwiązany spór o Trybunał Konstytucyjny”. Wśród sędziów powszechnie zostało to odebrane jako sygnał, że planowane zmiany mogą być niezgodne z obowiąującym porządkiem konstytucyjnym, a w szczególności naruszać zasady trójpodziału władzy, niezależności sądów i niezawisłości sędziów. Powyższe zapowiadane zmiany dotyczyć mają zasad postępowania dyscyplinarnego w taki sposób, aby w tym zakresie wyłączyć kompetencję korporacji sędziowskiej, przy czym minister wymienił dwie potencjalne możliwości rozważane w tym zakresie. Pierwszą stanowi wprowadzenie rodzaju trybunałów ludowych, w których „czynnik społeczny” orzekałby, „czy doszło do złamania zasad czy nie, a nie koledzy z korporacji”. Zgodnie z drugą koncepcją dla rozstrzygania spraw dyscyplinarnych sędziów miałaby zostać utworzona izba dyscyplinarna przy Sądzie Najwyższym (być może również z udziałem „czynnika społecznego”).

Kolejna z zasadniczych zmian dotyczyłaby samej organizacji wymiaru sprawiedliwości. Obecnie istniejąca trójszczeblowa struktura sądownictwa powszechnego, na którą składają się sądy rejonowe, sądy okręgowe i sądy apelacyjne, ma zostać zastapiona przez strukturę dwuszczeblowa, przy czym nie jest jasne, czy w ramach tej reorganizacji likwidacji miałby ulec obecnie najniższy poziom sądów powszechnych, tj. sądy rejonowe, czy też poziom najwyższy, tj. sądy apelacyjne. Ma zostać stworzone „uniwersalne” stanowisko „sędziego sądu powszechnego", co umożliwi weryfikację wszystkich nominacji sędziowskich. Inna koncepcja mówi o połączeniu wszystkich sądów rejonowych w ramach wielkich sądów okręgowych, gdzie dotychczasowe sądy rejonowe staną się jedynie ich wydziałami zamiejscowymi, co pozwoli dowolnie przerzucać pomiędzy nimi sędziów. Jeśli takie rozwiązanie zostanie wprowadzone, konstytucyjna zasada nieprzenoszalności sędziów stanie się iluzją. W'śród sędziów powszechny jest pogląd, że zapowiadana reorganizacja ma być tylko pretekstem, podobnie jak było to w przypadku reorganizacji prokuratury, do obsadzenia stanowisk prezesów sądów przez zaufanych ministra i usunięcia ze stanowiska sędziów, którzy nie zgadzają się z obraną polityką projektowanych zmian w sądownictwie. Do tej pory rząd powołany przez Prawo i Sprawiedliwość nie przeprowadził jeszcze zapowiadanej, gruntownej reformy sąownictwa. Nie oznacza to jednak, że obecny rząd ani parlament nie podejmują licznych działań mających wpływ na sposób funkcjonowania sądów powszechnych. Działania te można podzielić na dwie kategorie. Pierwsza z nich polega na podejmowaniu przez prezydenta i ministra sprawiedliwości działań, które maja poszerzyć kompetencje władzy wykonawczej wobec władzy sądowniczej w oparciu o sprzyjajaccą egzekutywie interpretację obecnie istniejących przepisów. Tego rodzaju działania budzą poważne wątpliwości prawne i są niewątpliwie sprzeczne z dotychczasowymi zwyczajami, prowadząc do zmiany wypracowanej przez lata równowagi władz. Do najważniejszych tego rodzaju działań należy zaliczyć ułaskawienie przez prezydenta byłego szefa Centralnego Biura Antykorupcyjnego, odmowa przez prezydenta nominacji 10 sędziów sądów powszechnych oraz cofnięcie delegacji jednej z sędziów do Sądu Okręgowego w Warszawie. Druga kategoria podjętych do tej pory działań w wymiarze sprawiedliwości to zmiany legislacyjne, w tym zarówno te już dokonane, jak i będące w stadium oficjalnych projektów ustaw i innego rodzaju aktów prawnych. 
Przechodząc do bardziej szczegółowego omówienia działań z pierwszej wyżej wzmiankowanej kategorii, chronologicznie najwcześniejszą było ułaskawienie przez prezydenta Andrzeja Dudę byłego szefa Centralnego Biura Antykorupcyjnego Mariusza Kamińskiego oraz jego trzech współpracowników. Osoby te zostały skazane przez Sąd Rejonowy w Warszawie za przekroczenie uprawnień i nielegalne działania operacyjne, za co Mariuszowi Kamińskiemu wymierzono karę 3 lat pozbawienia wolności oraz 10 lat zakazu zajmowania stanowisk w administracji publicznej ${ }^{3}$. Następnie od wydanego w sprawie wyroku wniesione zostały apelacje. Jednak w listopadzie 2015 r., przed rozpoznaniem apelacji, prezydent ułaskawił Mariusza Kamińskiego i pozostałych nieprawomocnie skazanych w tej sprawie. Decyzja prezydenta o ułaskawieniu wzbudziła bardzo wiele kontrowersji, i to nie tylko w punktu widzenia zasadności jej podjęcia, ale i prawnej dopuszczalności takiego działania. O ile nigdy nie budziło wątpliwości, że Prezydent ma prawo ułaskawiać osoby prawomocnie skazane, o tyle był to pierwszy przypadek w powojennej historii Polski, w której ułaskawienie zostało zastosowane wobec osoby, co do której wyrok sądu pierwszej instancji nie zdążył się uprawomocnić, a więc kwestia odpowiedzialności karnej osoby nie została ostatecznie rozstrzygnięta ${ }^{4}$. Co więcej, decyzja o ułaskawieniu została wydana bez zachowania trybu postępowania przewidzianego w Kodeksie postępowania karnego, a nawet bez zapoznania się przez prezydenta, bądź pracowników jego kancelarii, z aktami sprawy, a więc miała charakter całkowicie arbitralny. Na marginesie należy dodać, że niezwłocznie po ułaskawieniu nieprawomocnie skazany, m.in. za nielegalne działania operacyjne, Mariusz Kamiński został powołany na stanowisko ministra-koordynatora Służb Specjalnych, co jest stanowiskiem immanentnie związanym ze stosowaniem technik operacyjnych, co musi budzić zastrzeżenia z punktu widzenia ochrony praw i wolności obywatelskich.

Kolejna kontrowersyjną decyzja prezydenta Andrzeja Dudy była odmowa wręczenia nominacji 10 sędziom przedstawionym przez Krajową Radę Sadownictwa, co nastapiło 22 czerwca 2016 r. Zgodnie z dotychczasowa praktyką wręczanie nominacji sędziowskich osobom, które wcześniej brały udział $\mathrm{w}$ przeprowadzanych $\mathrm{w}$ poszczególnych sądach konkursach na stanowiska sędziów, a następnie były wskazywane przez Krajową Radę Sądownictwa, stanowiło uprawnienie honorowe Prezydenta RP. Jedyna podobna do obecnej sytuacja odmowy wręczenia nominacji sędziowskich w powojennej historii

${ }^{3}$ Stan faktyczny sprawy polegał na tym, że w 2007 r., w okresie, kiedy pierwszy raz u władzy było Prawo i Sprawiedliwość, kierowane przez Mariusza Kamińskiego Centralne Biuro Antykorupcyjne rozpoczęło prowokację wobec szefa koalicyjnej wówczas dla PiS-u partii Samoobrona, prowokacji, która miała zakończyć się wręczeniem kontrolowanej łapówki. W uzasadnieniu wydanego w tej sprawie wyroku sąd stwierdził, że Centralne Biuro Antykorupcyjne podżegało do korupcji w sytuacji, gdy nie było podstaw prawnych i faktycznych do wszczęcia tego rodzaju operacji antykorupcyjnej.

${ }^{4}$ Należy w tym miejscu zaznaczyć, że bardzo ogólny przepis art. 139 Konstytucji nie rozstrzyga, na jakim etapie może nastapić ułaskawienie, jednakże jedyne przepisy wykonawcze rangi ustawowej są zawarte w Kodeksie postępowania karnego, gdzie szczegółowe postanowienia w tym zakresie znajdują się w dziale XII zatytułowanym „Postępowanie po uprawomocnieniu się orzeczenia”. 
Polski zdarzyła się w 2007 r., również za rządów Prawa i Sprawiedliwości, kiedy ówczesny prezydent Lech Kaczyński odmówił nominacji 9 sędziom. Uprawnienie Prezydenta do odmowy wręczenia nominacji sędziowskich budzi poważne wattpliwości prawne, jako że nie jest wprost przewidziane w Konstytucji. W tym miejscu należy zaznaczyć, że sędziowie, którym w 2007 r. Lech Kaczyński odmówił nominacji sędziowskich, wyczerpali przysługujące im środki prawne w celu wzruszenia tej decyzji, jednak zarówno orzeczenia Trybunału Konstytucyjnego ${ }^{5}$, jak i Naczelnego Sądu Administracyjnego były dla nich negatywne. Nie zmienia to jednak faktu, że wyłącznie ci prezydenci Polski, którzy byli nominatami Prawa i Sprawiedliwości, uzurpowali sobie prawo do odmowy nominowania sędziów. Omawiając decyzję prezydenta Andrzeja Dudy, należy również podkreślić jej całkowicie arbitralny charakter, który wynika $\mathrm{z}$ faktu, że nie zawiera ona żadnego uzasadnienia. Taki charakter decyzji otworzył drogę do spekulacji prasowych, z których wynika, że przynajmniej $\mathrm{w}$ odniesieniu do niektórych z nienominowanych sędziów przyczyną mógł być fakt, że prowadzili oni postępowania, w których wydali orzeczenia niekorzystne dla członków Prawa i Sprawiedliwości. Dążenie do wzmocnienia wpływu Prezydenta na proces nominacji sędziowskich znajduje również wyraz w zmianach ustawy o Krajowej Radzie Sądownictwa, o których będzie mowa poniżej.

Potencjalny motyw odwetu na sędziach, którzy wydali decyzje niekorzystne dla członków partii rządzącej, jeszcze wyraźniej pojawia się w odniesieniu do indywidualnej decyzji ministra sprawiedliwości-prokuratora generalnego Zbigniewa Ziobry, na mocy której cofnięto jednej z sędziów Sądu Rejonowego w Warszawie delegację do orzekania w sądzie wyższej instancji. Podjęta na początku października 2016 r. decyzja była o tyle zaskakująca, że do pracy sędzi nie było najmniejszych zastrzeżen, w szczególności nie miała ona prowadzonych żadnych postępowań dyscyplinarnych, a jej praca była wysoko oceniana przez przełożonych. Jak ustalono, kilka lat wcześniej sędzia prowadziła postępowanie w sprawie, w której jedną ze stron był obecny minister sprawiedliwości-prokurator generalny Zbigniew Ziobro. Obecny minister proces ten przegrał, w jego trakcie sędzia ukarała Zbigniewa Ziobrę karą pieniężna za nieusprawiedliwione niestawiennictwo, a na zakończenie postępowania zadecydowała, że to on będzie musiał ponieść koszty postępowania. Znamienne jest, że decyzję o cofnięciu sędzi delegacji Zbigniew Ziobro podpisał osobiście, bez zastępstwa. Do tych publikacji odniosło się Ministerstwo Sprawiedliwości, wydając oficjalny komunikat, w którym stwierdzono, że przyczyną odmowy nominacji był fakt, że sędzia w prowadzeniu prostej, choć głośnej medialnie sprawy wykazała się „wyjątkową nieudolnością". Jak się następnie okazało, chodziło o sprawę, z którą sędzia miała tylko krótki kontakt polegający na tym, że odmówiła rozpoznania sprawy o wypadek drogowy w trybie przyspieszonym, gdyż oceniła, że poczytalność sprawczyni wypadku budzi wątpliwości.

5 Trzech sędziów Trybunału Konstytucyjnego złożyło jednak wówczas zdania odrębne, podkreślając, że przeprowadzanie złożonej, wieloetapowej procedury wyboru sędziów byłoby pozbawione sensu w sytuacji, gdyby mogła ona zostać przekreślona arbitralną decyzją Prezydenta. Co więcej, przyznanie Prezydentowi takiego uprawnienia podważałoby kompetencje innego z konstytucyjnie umocowanych organów, tj. Krajowej Rady Sądownictwa. 
Należy podkreślić, że późniejsze badanie sądowo-psychiatryczne sprawczyni wypadku potwierdziło jej zniesioną poczytalność, a zatem o żadnej nieudolności sędzi mowy być nie może. Stanowisko w tej sprawie zajęła Krajowa Rada Sądownictwa, w której oświadczeniu czytamy: „Krajowa Rada Sądownictwa negatywnie ocenia działania Ministra Sprawiedliwości, gdyż podważają one zaufanie obywateli do sądu, a decyzja o odwołaniu delegacji nie znajduje żadnych uzasadnionych podstaw".

III. Przechodząc do omówienia drugiej kategorii podjętych do tej pory przez rząd Prawa i Sprawiedliwości działań w obszarze sądownictwa, polegających na już wprowadzonych, czy też będących w fazie projektów, zmian legislacyjnych, na wstępie należy zaznaczyć, że o ile każda z tych inicjatyw ustawodawczych sama w sobie mogłaby wydawać się naturalna, o tyle jednak ich nagromadzenie w krótkim czasie, w połączeniu z ogólną tendencją do zwiększenia możliwości wpływania na funkcjonowanie sądów oraz wyraźnie zaznaczona zwiększoną represyjnością tych środków wobec środowiska sędziowskiego (w porównaniu z innymi kategoriami funkcjonariuszy publicznych) musi już budzić niepokój. O ile nikt nie kwestionuje potrzeby zmian w wymiarze sprawiedliwości ukierunkowanych na zwiększenie efektywności działania sądów, o tyle trudno znaleźć uzasadnienie akurat takiego kierunku zmian.

Jedną z nowości wprowadzonych przez nową ustawę o prokuraturze jest utworzenie, na szczeblu Prokuratury Krajowej, Wydziału Spraw Wewnętrznych, który ma zajmować się „prowadzeniem i nadzorowaniem postępowań przygotowawczych w sprawach o umyślne przestępstwa ścigane z oskarżenia publicznego popełnione przez sędziów, prokuratorów lub asesorów sądowych lub prokuratorskich". Wydział spraw wewnętrznych kadrowo tworzy Minister Sprawiedliwości-Prokurator Generalny. Fakt umieszczenia tej nowej jednostki na najwyższym szczeblu organizacyjnym prokuratury zdaje się sugerować, że korupcja wśród sędziów i prokuratorów stanowi w Polsce poważny problem, który wymagał podjęcia zdecydowanych działań. Jednak statystyka zdecydowanie podważa tezę, aby zachodziła konieczność utworzenia tego rodzaju wyspecjalizowanej jednostki. Jak się okazuje, po ponad 6 miesiącach swojego funkcjonowania, wliczając w to sprawy wszczęte przed utworzeniem Wydziału Spraw Wewnętrznych, sa w nim prowadzone zaledwie 24 postępowania, z czego 19 dotyczacych prokuratorów, a tylko 5 dotyczących sędziów. Biorąc pod uwagę, że Polsce orzeka około 10000 sędziów oraz swoje obowiązki wykonuje około 7000 prokuratorów, wskazaną liczbę postępowań należy uznać za śladowa ${ }^{6}$, a fakt utworzenia tego rodzaju jednostki trudno postrzegać inaczej, niż jako próbę zdeprecjonowania, a może i zastraszenia środowisk prokuratorskiego i sędziowskiego. To rozwiąanie, zdaniem Krajowej Rady Sądownictwa, narusza art. 32 Konstytucji, który gwarantuje każdemu obywatelowi równe

\footnotetext{
${ }^{6}$ Należy zaznaczyć, że utworzenie Biura Spraw Wewnętrznych nie jest jedyną specyfika nowej organizacji prokuratury, która nie ma należytego uzasadnienia w faktycznej strukturze przestępczości. Równie nietypowe jest utworzenie na szczeblu prokuratur regionalnych (a więc szczeblu bardzo wysokim) jednostek, których przedmiotem specjalizacji jest prowadzenie spraw dotyczących błędów w sztuce lekarskiej, przy czym jednostki te nierzadko są dublowane również na szczeblu prokuratur okręgowych.
} 
traktowanie ${ }^{7}$. Tymczasem wprowadzone rozwiązanie wyłącza z prowadzenia spraw przeciwko sędziom i prokuratorom właściwe prokuratury i przekazuje sprawy, na podstawie arbitralnej decyzji, do specjalnej jednostki. Dlatego Krajowa Rada Sądownictwa zaskarżyła omawiane rozwiązanie do Trybunału Konstytucyjnego.

Jak się wydaje, w podobnych kategoriach należy ocenić projekt ustawy z września 2016 r., na podstawie którego wprowadza się kwalifikowany typ przestępstwa łapownictwa biernego. Zgodnie z projektowanym przepisem przyjęcie $\mathrm{w}$ związku z toczacym się postępowaniem korzyści majątkowej lub osobistej przez sędziego, ławnika lub prokuratora ma stanowić zbrodnię (a więc najcięższą kategorię przestępstw przewidzianą w polskim Kodeksie karnym), zagrożoną karą od 3 do 15 lat pozbawienia wolności ${ }^{8}$. O ile należy zgodzić się, że przyjęcie przez sędziego łapówki stanowi bardzo ciężkie przestępstwo, o tyle od 1989 r. sytuacje przyjęcia przez sędziów łapówek były tak sporadyczne, że względy polityki kryminalnej w żaden sposób nie uzasadniaja proponowanego zaostrzenia przepisów. Znamienne jest, że raport GRECO wyróżnia Polskę jako ten kraj postkomunistyczny, w którym nie ma problemu z korupcją w wymiarze sprawiedliwości. Trudno również znaleźć uzasadnienie wyraźnego „wyróżnienia" sędziów, prokuratorów i ławników na tle innych funkcjonariuszy administracji publicznej którzy potencjalnie w równym stopniu mogą być adresatami propozycji korupcyjnych, a których decyzje i działania moga wpływać na sytuacje znacznie większej ilości osób (jak członkowie rządu, parlamentu, czy osoby pełniace kierownicze funkcje w administracji publicznej), niż działania sędziów co do zasady rozstrzygajacych spory indywidualne.

Rada Ministrów 5 września 2016 r. przyjęła projekt ustawy zakładający, że oświadczenia majątkowe sędziów maja być jawne, przy czym za umyślne podanie nieprawdy w oświadczeniu majątkowym sędziom grozi odpowiedzialność karna. Obecnie sędziowie również składają oświadczenia o stanie majątkowym, jednak nie sa one powszechnie dostępne, gdyż sa przekazywane do właściwego urzędu skarbowego, natomiast za podanie nieprawdy w oświadczeniu majątkowym sędziom grozi wyłącznie odpowiedzialność dyscyplinarna. Krytycy projektu zasadnie podnosza, że wprowadzenie powszechnej jawności oświadczeń majątkowych sędziów może sprowadzać na nich niebezpieczeństwo, zwłaszcza w stosunku do sędziów prowadzących sprawy przeciwko zorganizowanej przestępczości. Ten sam projekt ustawy wprowadza również ogólne zaostrzenie odpowiedzialności dyscyplinarnej sędziów, wydłużając okres, w którym będzie możliwe wszczęcie postępowania dyscyplinarnego, z 3 do 5 lat i wprowadzając nieznaną do tej pory karę dyscyplinarną w postaci obniżenia wynagrodzenia sędziego o 5-15\% na okres od 6 miesięcy do 2 lat, przy czym co do zasady orzeczenie wobec sędziego kary dyscyplinarnej będzie skutkowało pozbawieniem sędziego możliwości awansu na okres 5 lat oraz pozbawieniem go możliwości piastowania stanowisk funkcyjnych.

\footnotetext{
${ }^{7}$ Powołany przepis stanowi: „Wszyscy są równi wobec prawa. Wszyscy mają prawo do równego traktowania przez władze publiczne".

${ }^{8} \mathrm{~W}$ typie podstawowym przestępstwo to jest zagrożone karą od 6 miesięcy do 8 lat pozbawienia wolności.
} 
IV. Zasadnicze znaczenie dla ochrony niezależności sądów i niezawisłości sędziów w Polsce pełni umocowany konstytucyjnie kolegialny organ w postaci Krajowej Rady Sądownictwa, w której skład wchodzą wybierani przez organy samorządu sędziowskiego sędziowie, wybrani przez Sejm i Senat posłowie i senatorowie, Prezes Sądu Najwyższego, Prezes Naczelnego Sądu Administracyjnego, Minister Sprawiedliwości oraz przedstawiciel Prezydenta. Do konstytucyjnie zagwarantowanych uprawnień Rady należy m.in. wybór kandydatów na sędziów i przedstawienie prezydentowi wniosków o ich powołanie, uchwalenie zbioru zasad etyki zawodowej sędziów, oraz opiniowanie projektów aktów normatywnych dotyczących sądownictwa. Rada jest także uprawniona do występowania do Trybunału Konstytucyjnego z wnioskami o zbadanie zgodności z Konstytucją aktów normatywnych dotyczących niezależności sądów i niezawisłości sędziów. Biorąc pod uwagę wymienione uprawnienia Rady i pełnioną przez nią funkcję, wszelkie zmiany zakresu jej uprawnień bądź statusu jej członków mogą łatwo naruszyć zasadę wzajemnej równowagi władz. Z tym większym zaniepokojeniem należy odnotować kierunek zmian podjętych w tym zakresie przez obecną większość parlamentarna. Zgodnie z przygotowanym projektem ustawy zostały wprowadzone m.in. zmiany w zasadach wyboru sędziów wchodzących w skład Rady, co zostało połączone z wygaszeniem kadencji dotychczasowych jej członków. Dotyczyć to ma jedynie sędziów, a nie pozostałych członków Krajowej Rady Sądownictwa. Kolejna zmiana poszerza również kompetencje Prezydenta w procesie nominacyjnym sędziów w ten sposób, że zobowiązuje Radę, w sytuacji gdy na dane stanowisko zgłosi się więcej niż jeden kandydat, do przedstawienia Prezydentowi co najmniej dwóch kandydatów na stanowisko sędziowskie. Zgodnie z opinią Krajowej Rady Sądownictwa obydwie z wymienionych zmian sa niezgodne z Konstytucja. W szczególności wygaszenie kadencji dotychczasowych członków Rady narusza postanowienie art. 187 ust. 3 Konstytucji, zgodnie z którym kadencja wybranych członków Rady, którzy są sędziami, trwa 4 lata. Z kolei zobowiązanie Rady do przedstawienia co najmniej 2 kandydatów na każde stanowisko sędziowskie pozostawia w rękach Prezydenta prawo wyboru kandydata właściwego (i to bez wskazywania jakichkolwiek kryteriów dokonania wyboru i bez możliwości odwołania się osób zainteresowanych od decyzji Prezydenta) w sytuacji, gdy zgodnie z konstytucją tylko Krajowa Rada Sądownictwa ma kompetencje do wyboru sędziów, natomiast Prezydent - ma kompetencję wyłącznie do ich powoływania. Za niekonstytucyjne Rada uznała również postanowienie o odebraniu prezesom i wiceprezesom sądów prawa do członkostwa w Radzie. Do wprowadzenia ustawy o Krajowej Radzie Sądownictwa pod obrady Sejmu dojdzie zapewne po przejęciu kontroli nad Trybunałem Konstytucyjnym.

Rola Krajowej Rady Sądownictwa jest tym bardziej istotna, że obsadza ona również wolne stanowiska do Sądu Najwyższego, który z kolei kontroluje np. ważność wyborów parlamentarnych i prezydenckich. Sądy apelacyjne, które są dzisiaj drugą instancją dla poważniejszych spraw, rozpoznaja ponad 100000 spraw rocznie, co oznaczałoby, że do Sądu Najwyższego może wpłynąć nawet 10 -krotnie więcej spraw niż obecnie. Takie rozwiązanie zatem albo spa- 
raliżuje działalność Sądu Najwyższego, albo spowoduje konieczność takiego powiększenia jego liczebności, że jego obecni sędziowie staną się tylko nic nie znaczącą mniejszością w jego składzie.

26 stycznia 2017 r. wpłynał do zaopiniowania Krajowej Rady Sadownictwa projekt zmiany ustawy o KRS. Projekt ten fundamentalnie i wbrew Konstytucji zmienia materię ustroju Rzeczypospolitej Polskiej. Co ciekawe, wiceminister Marcin Warchoł zakreślił KRS termin do złożenia opinii do dnia 31 stycznia 2017 r. Oznaczało to, że Rada ma wydać opinię w tak ważnej sprawie $\mathrm{w}$ cztery dni, wliczając $\mathrm{w}$ to sobotę i niedzielę. Rada, jak wiadomo, jest kolegialnym organem składającym się także z sędziów, którzy sądza w swoich sądach. Minister wie o tym bardzo dobrze i zna też harmonogram comiesięcznych posiedzeń Rady. Wyraźnie oznacza to, że Ministerstwu zależy jedynie na tym, by formalnie, do czego obliguje ich ustawa, przesłali projekt do KRS, nie dając jednak realnej możliwości wydania opinii w tak fundamentalnej sprawie.

Projekt ten zakłada wygaszenie $\mathrm{w}$ trzy miesiące od wejścia w życie nowych przepisów kadencji wszystkich sędziów w KRS, ale nie polityków czy przedstawiciela Prezydenta. Ustawodawca nie dostrzega, że skoro z art. 187 ust. 1 Konstytucji RP wynika, że Sejm wybiera posłów, a Senat senatorów, to sędziów - członków Rady powinni wybierać sędziowie. Podkreślenia wymaga, że wbrew sugestiom Ministra Sprawiedliwości sędziowie sądów rejonowych biora obecnie udział w wyborze członków Rady. Sa oni bowiem członkami każdego zgromadzenia ogólnego sędziów. Nie jest zatem prawdziwe stwierdzenie Ministra Sprawiedliwości, by o wyborze członków KRS „decydowały sędziowskie elity".

Propozycja Ministra Sprawiedliwości, zakładająca wybór 15 sędziów członków Rady przez Sejm, narusza art. 187 ust. 1 Konstytucji RP. Kandydatów ma zgłaszać Prezydium Sejmu lub 50 posłów, ale i tak o tym, kogo przedstawić Sejmowi, decydowałby Marszałek Sejmu. Może on, jeśli zechce, zasięgać niewiążących opinii stowarzyszeń sędziowskich.

Konstytucja nakłada na Krajową Radę Sądownictwa obowiązek stania na straży niezależności sądów i niezawisłości sędziów, jak również odrębności władzy sądowniczej od innych władz. Ogłoszony zamiar zmiany przepisów, zakładający, że także sędziowie - członkowie Rady mają być wybierani przez większość parlamentarna, doprowadzi do upolitycznienia Rady oraz pozbawi organy samorządu sędziowskiego realnego wpływu na proces wyboru kandydatów na sędziów. Należy podkreślić, że członkowie Rady, o których mowa w art. 187 ust. 1 pkt 2 Konstytucji RP, łączą sprawowanie mandatu członka Rady z pracą orzecznicza, wykonują na co dzień obowiązki sędziowskie, które stanowią podstawę sprawowanego przez nich urzędu sędziego. Proponowane rozwiązanie, w którym będą musieli uzyskać poparcie polityków zasiadajacych w Sejmie, podważy zaufanie społeczeństwa do niezależności i niezawisłości władzy sądowniczej. Propozycja jest również nie do pogodzenia z zaleceniami Europejskiej Sieci Rad Sądownictwa (ENCJ). Wynika z nich bowiem wyraźnie, że sędziów do składu rady powinni wybierać sędziowie. Co więcej, to sędziowie powinni stanowić większość w KRS. 
Bardzo niebezpieczne jest również wygaszanie kadencji już urzędujących członków Rady. A to dlatego, że każdy następny rząd będzie się mógł na to powoływać i twierdzić, że może zmieniać ustawą zwykłą ustanowioną w Konstytucji czteroletnią kadencję. I zawsze, kiedy nie będzie mu się podobał kolejny skład Rady, będzie mógł w ten sposób go wymieniać. Istotne jest również to, że ustawa przewiduje wygaszenie kadencji jedynie sędziów. A więc pamięć instytucjonalna Rady zostanie przekazana tylko przez polityków.

Projekt ustawy zakłada także zmiany dotyczace ustroju Rady i przekształcenia jej w dwa „Zgromadzenia” (,Izby”). Pierwsze Zgromadzenie KRS miałoby się składać z 10 członków (Pierwszego Prezesa Sądu Najwyższego, Prezesa Naczelnego Sądu Administracyjnego, Ministra Sprawiedliwości, osoby powołanej przez Prezydenta RP, czterech posłów i dwóch senatorów), a Drugie Zgromadzenie KRS z 15 członków wybranych spośród sędziów Sądu Najwyższego, sądów powszechnych, sądów administracyjnych i sądów wojskowych. Propozycja zakłada, że dla podjęcia uchwały przez Radę wymagane będzie jej przyjęcie przez oba Zgromadzenia, obradujące oddzielnie. Propozycja ta w rażący i oczywisty sposób narusza art. 186 i art. 187 Konstytucji RP. Nadaje ona bowiem niejednakową rangę poszczególnym członkom Rady, podczas gdy Konstytucja określa Krajową Radę Sądownictwa jako jednolity organ o jednoznacznie określonym składzie i nie różnicuje statusu członków Rady.

To postanowienie może stanowić ponadto próbę obejścia przepisów gwarantujących równość głosów członków Rady. Zakłada bowiem, że głos każdego z 10 członków Pierwszego Zgromadzenia KRS będzie silniejszy niż głos każdego z 15 członków Drugiego Zgromadzenia KRS, a zatem naruszy zasadę materialnej równości głosów członków Krajowej Rady Sądownictwa. Co budzi jednak największe zastrzeżenia, to to, że propozycja Ministra oznacza, że dla przyjęcia jakiejkolwiek uchwały Rady niezbędne będzie uzyskanie poparcia Pierwszego Zgromadzenia KRS, w którym zdecydowaną większość będą zawsze mieli politycy (Minister Sprawiedliwości, czterech posłów i dwóch senatorów). Taka organizacja wewnętrzna Rady uniemożliwi wykonywanie jej podstawowego obowiązku, jakim jest stanie na straży niezależności sadów i niezawisłości sędziów. Jednocześnie może dojść do wzajemnego zablokowania działań Rady przez dwie izby, gdyby okazało się, że np. sędziowie wybrani przez polityków zechcą działać zbyt samodzielnie.

Projekt Ministra powiela ponadto rozwiązanie dotyczace zmiany zasad powoływania sędziów przewidziane w rządowym projekcie ustawy o zmianie ustawy o Krajowej Radzie Sądownictwa z maja 2016 r. (który Minister wycofał, wskazując, że najpierw musi się „rozwiązać” kwestia Trybunału Konstytucyjnego).

Zgodnie z art. 179 Konstytucji RP i obecnie obowiązującymi przepisami ustaw ustrojowych sądownictwa, Prezydent RP powołuje sędziów na wniosek Krajowej Rady Sąownictwa. Projekt Ministra Sprawiedliwości zamierza - bez zmiany Konstytucji - do wprowadzenia zasady, zgodnie z która Prezydent RP miałby powoływać sędziego spośród co najmniej dwóch kandydatów przedstawionych mu przez Krajową Radę Sądownictwa. Propozycja ta w oczywisty sposób narusza art. 179 Konstytucji RP, gdyż Konstytucja 
wyraźnie odróżnia powoływanie sędziów przez Prezydenta RP „na wniosek Krajowej Rady Sądownictwa” od „powoływania spośród kandydatów przedstawionych” przez odpowiedni organ. Prezydent zatem nie „wybiera” a „powołuje”. Ten drugi tryb nominacji Konstytucja przewiduje np. dla obsady stanowisk Pierwszego Prezesa Sądu Najwyższego, Prezesa Naczelnego Sądu Administracyjnego oraz Prezesa i Wiceprezesa Trybunału Konstytucyjnego. Gdyby zatem ustawodawca chciał w taki sposób ukształtować tryb powoływania sędziów, użyłby w art. 179 Konstytucji RP takiego samego sformułowania, jak zastosowane w art. 183 ust. 3, art. 185 i art. 194 ust. 2 Konstytucji RP. Co ciekawe, prezydent osobiście na spotkaniu z Prezydium KRS we wrześniu 2016 r. negatywnie wypowiedział się o tym projekcie.

V. Kolejne zmiany legislacyjne, które zwiększają wpływ Ministra Sprawiedliwości na sposób działania sądów, dotyczą dyrektorów w sądach, którzy odpowiedzialni są za finansową stronę działalności poszczególnych sądów. Obecnie dyrektorzy podlegają prezesom sąów, a wybierani sąd w drodze konkursów. Zgodnie z projektem dyrektorzy sądów będą podlegać bezpośrednio Ministrowi Sprawiedliwości, który będzie ich powoływał bez procedury konkursowej. Projekt ustawy nie wskazuje również podstaw odwołania dyrektorów, pozostawiając to arbitralnej decyzji Ministra Sprawiedliwości. Minister, który uzyska decydujący i niekontrolowany wpływ na finanse sądów, jest w stanie sparaliżować pracę każdego sądu, który oceni jako niedziałającego po jego myśli.

Inną charakterystyczną dla ostatniego okresu zmianą legislacyjną na obszarze wymiaru sprawiedliwości była zmiana Regulaminu urzędowania sądów, wprowadzająca zwiększenie zakresu pensum obciążenia orzeczniczego rzeczników prasowych sądów, z których znaczna część zdecydowanie opowiadała się po stronie zachowania zasad trójpodziału władzy i niezawisłości sędziowskiej. W ten sposób zwłaszcza rzecznicy w dużych sądach, gdzie obciążenie pracą jest ogromne, nie są w stanie należycie wywiązywać się z obowiązków wynikających z ich funkcji, a sądy stają się „nieme”. Zarazem ostatnio wprowadzona została zmiana w Kodeksie postępowania karnego (art. 360 § 2), zgodnie z którą na etapie postępowania sądowego (jego gospodarzem formalnie jest sad), to jednak prokurator de facto ma pełna kontrolę nad tym, w jakim przypadku będzie wyłączona jawność rozprawy. Wiele osób uważa, że to znak, iż prokuratura będzie chciała prowadzić procesy pokazowe, do czego potrzebna jest kontrola nad jawnością rozprawy.

Ministerstwo przygotowało także projekt zmieniający zasady wyboru asesora. Miałby go wybierać Minister Sprawiedliwości. Takie rozwiązanie zostało już raz uznane przez Trybunał za niekonstytucyjne, ponieważ Europejski Trybunał Praw Człowieka w Strasburgu stwierdził, że taki tryb wyboru i powoływania asesora nie spełnia warunku „niezawisłego sądu”. Wskazać należy jednocześnie, że Minister może obecnie w każdym czasie powołać i odwołać Dyrektora Krajowej Szkoły Sądownictwa i Prokuratury i decydować o tym, kto zostanie jej wykładowca. Jednocześnie Minister chce wprowadzić jednoznaczne zmiany dające mu całkowitą swobodę w obsadzaniu i zwalnia- 
niu prezesów sądów. Właśnie procedowana jest ustawa dotycząca dyrektorów sądów, którzy mają być dowolnie powoływani i odwoływani przez Ministra, bez dotychczasowych konkursów.

W styczniu 2017 r. weszła w życie ustawa o publikacji oświadczeń majątkowych sędziów w Internecie. Co ciekawe, ten sam ustawodawca w uzasadnieniu ostatniego projektu o Trybunale Konstytucyjnym zaznacza, że sędziowie TK, wybrani w czasie, gdy nie było przepisów dotyczących ich jawnych oświadczeń majątkowych, mogą dobrowolnie przejść w stan spoczynku, gdyż przepis o jawności oświadczeń głęboko ingeruje w ich życie osobiste i prawo do prywatności. Jednocześnie wobec sędziów sądów powszechnych uznaje, że to dobry krok do budowania zaufania do sądów pomimo faktu, że gdy sędziowie obejmowali stanowiska, nie składali żadnych, ani jawnych, ani niejawnych, oświadczeń.

VI. Wszystkie wyżej wymienione działania legislacyjne obecnego parlamentu, jak i działania faktyczne prezydenta i władz wykonawczych, w połączeniu z narastającym kryzysem wokół Trybunału Konstytucyjnego sprawiły, że środowisko sędziowskie poczuło, że jego status umożliwiajacy sprawowanie wymiaru sprawiedliwości w sposób niezawisły i niezależny jest mocno zagrożony. W związku z powyższym pod auspicjami Krajowej Rady Sądownictwa oraz stowarzyszeń sędziowskich 3 września 2016 r. w Warszawie odbył się nadzwyczajny kongres sędziów polskich, w którym wzięło udział około 1000 spośród 10000 sędziów sądów powszechnych ${ }^{9}$. Po trwających wiele godzin obradach Kongres podją 3 uchwały, w których znalazły się m.in. postulaty dotyczące przekazania nadzoru administracyjnego nad sądami Pierwszemu Prezesowi Sądu Najwyższego (obecnie sprawuje go Minister Sprawiedliwości-Prokurator Generalny), wprowadzenia zasady tworzenia i znoszenia sądów tylko w drodze ustawy, ograniczenie wpływu czynnika politycznego na wybór sędziów, poszerzenie uprawnień samorządu sędziowskiego oraz przestrzegania zasady ochrony praw nabytych przez sędziów przy wprowadzaniu przyszłych zmian w strukturze sadownictwa. W kolejnej uchwale Kongres wezwał władzę wykonawczą do poszanowania i publikowania wyroków Trybunału Konstytucyjnego oraz sprzeciwił się arbitralnej odmowie powołania przez prezydenta kandydatów na sędziów przedstawionych przez Krajową Radę Sądownictwa, a także odmowie zaprzysiężenia wybranych zgodnie z prawem sędziów Trybunału Konstytucyjnego. Po opublikowaniu uchwał Kongresu szereg zgromadzeń sędziów sądów okręgowych i sądów apelacyjnych podjęło uchwały w pełni popierające stanowisko Kongresu.

W tym miejscu warto również nadmienić, że 26 listopada 2016 r. odbył się w Krakowie XII Krajowy Zjazd Adwokatury, podczas którego podjęto m.in. uchwałę następującej treści:

${ }^{9}$ Liczba sędziów zainteresowanych udziałem w kongresie była znacznie większa, jednak ograniczone możliwości lokalowe uniemożliwiły zorganizowanie zjazdu, w którym mogłaby wziąć udział większa liczba osób. 
[...] Ograniczanie niezależności władzy sądowniczej, niezawisłości sędziów, w tym sędziów Trybunału Konstytucyjnego, podważa zasady współczesnej demokracji. Konstytucja RP nie daje żadnemu organowi władzy ustawodawczej lub wykonawczej prawa do ingerowania w proces wydawania oraz publikacji orzeczeń Trybunału Konstytucyjnego, ani do oceny prawidłowości wyboru sędziów Trybunału Konstytucyjnego [...]. Permanentny proces zmian ustawowej regulacji zasad działania Trybunału Konstytucyjnego pozostaje w sprzeczności z ustrojowymi fundamentami Rzeczpospolitej, godzi w zasady tworzenia prawa, jego stabilność, a w konsekwencji skutkuje dysfunkcjonalnością filarów demokratycznego państwa prawnego. Sprzeciw budzi także pospieszne stanowienie ukierunkowanego na osiagnięcie doraźnych celów politycznych prawa. Wszelkie zmiany legislacyjne wymagaja konsultacji oraz aktywnego udziału przedstawicieli społeczeństwa obywatelskiego, a także przestrzegania zasady podziału i równoważenia się władz. [...] Z norm konstytucyjnych wynikają zasady, dzięki którym jednostka chroniona jest przed „demokratyczną dyktaturą” większości. Granice demokracji konstytucyjnej wyznacza prawo będące autonomiczną i równorzędną wartościa. Wszelkie naruszenia tych granic, niezależnie od tego, na jakiej opieraja się legitymacji, traktować należy jako zamach na podstawowe konstytucyjne wartości. Ich ochrona w każdym wypadku i w każdym czasie jest nasza podstawową powinnościa, od której nikt - ani Adwokatury jako instytucji, ani żadnego z adwokatów - zwolnić nie może.

VII. Celem niniejszego artykułu nie było kompleksowe omówienie wszystkich wprowadzonych zmian i podjętych działań na obszarze wymiaru sprawiedliwości przez rząd i parlament, które sprawują w Polsce władzę od października 2015 r. Takie omówienie w ramach jednego, nawet najbardziej obszernego, artykułu nie byłoby możliwe. Należy zaznaczyć, że poza wymienionymi w tym artykule wprowadzono także zmiany, które należy ocenić pozytywnie bądź przynajmniej można przypisać im dobre intencje i właściwy kierunek ${ }^{10}$.

Po prowadzonych konsekwentnie przez cały mijajacy rok działaniach mających na celu podporządkowanie bądź sparaliżowanie Trybunału Konstytucyjnego oraz wprowadzeniu zmian w ustawie o Prokuraturze zmierzających do jej podporządkowania czynnikowi politycznemu, wreszcie po podjęciu działań faktycznych mających na celu poszerzenie uprawnień władzy wykonawczej wobec sądów powszechnych oraz rozwiązań legislacyjnych o wydźwięku represyjnym wobec sędziów sądów powszechnych - nietrudno domyślić się, że reforma sądownictwa będzie zmierzała w kierunku ograniczenia niezależności sądów i niezawisłości sędziów. Co więcej, prace nad reforma sądownictwa powszechnego sa prowadzone w tajemnicy i bez konsultacji choćby z Krajowa Radą Sądownictwa. Ujawniony w ostatnich dniach, bezspornie sprzeczny z Konstytucja, projekt ustawy o zmianie ustawy o Krajowej Radzie Sądownictwa wprowadza nowy tryb wyboru sędziów - członków Rady przez parlament, który zmierza do upolitycznienia tego konstytucyjnego organu, stojącego przecież na straży niezależności sądów i niezawisłości sądów. Daje partii rządzącej możliwość wpływania na wybór sędziów, drogę ich awansu oraz postępowania dyscyplinarne. Działania tego nie sposób ocenić inaczej, niż jako otwarty zamach na niezależność sądów i niezawisłość sędziów sądów powszechnych.

${ }^{10}$ Za takie zmiany można np. uznać zmiany w ustawie o Prokuraturze czy w Regulaminie urzędowania sądów, zmierzające do „dociążenia” sprawami sędziów i prokuratorów pełniących stanowiska funkcyjne, aczkolwiek wydaje się, że powołane przepisy w niewystarczającym stopniu uwzględniają wpływ wielkości jednostek, którymi kierują osoby funkcyjne, na możliwość wykonywania przez nie dodatkowych zadań, bez szkody dla możliwości efektywnego kierowania jednostkami. 
Jak się wydaje, pewien pogląd na dalsze zamiary partii rządzącej wobec władzy sądowniczej daje opublikowany w Internecie, a przygotowany przez partię Prawo i Sprawiedliwość w 2010 r. projekt nowej konstytucji Polski. Projekt ten wprawdzie nie wszedł w życie i pod koniec 2015 r. został zdjęty ze strony internetowej po nagłośnieniu przez dziennikarzy, że zmierza do wprowadzenia rząów autorytarnych. Rzeczniczka partii Prawo i Sprawiedliwość skomentowała wówczas, że jest to tylko jedna z wielu dyskutowanych propozycji, która nie ma obowiązującego charakteru. Zgodnie z art. 145 ust. 2 wspomnianego projektu:

Sędzia, którego dotychczasowe postępowanie świadczy o niezdolności lub braku woli rzetelnego sprawowania urzędu, może zostać złożony z urzędu przez Prezydenta Rzeczypospolitej na wniosek Rady do spraw Sądownictwa wyrażony w uchwale podjętej większościa $3 / 5$ ustawowej liczby członków Rady po przeprowadzeniu określonego w ustawie postępowania z udziałem osoby, której dotyczy. Akt Prezydenta Rzeczypospolitej nie podlega zaskarżeniu.

Biorąc pod uwagę, że omawiany przepis umożliwia Prezydentowi odwołanie sędziego w oparciu o niedookreśloną klauzulę generalną i bez możliwości odwołania się od tej decyzji, należy uznać, że przepis ten nie tyle ogranicza, ile w zasadzie znosi niezawisłość sędziowską. Cytowane postanowienie projektu Konstytucji PiS przypomina postanowienie art. $61 \S 1$ ustawy o ustroju sądów powszechnych obowiązującej w czasach PRL, zgodnie z którym Rada Państwa, na wniosek Ministra Sprawiedliwości, mogła odwołać sędziego, jeżeli nie „dawał on rękojmi należytego wykonywania obowiązków sędziego". Powstaje tylko pytanie, czy na początku XXI w. w państwie położonym w centrum Europy godzi się poważnie brać pod uwagę powrót do instytucji o głęboko komunistycznym rodowodzie, uragającej zasadom demokratycznego państwa prawnego.

Na nadzwyczajnym Kongresie sędziów polskich 3 września 2016 r. jeden z najwybitniejszych autorytetów prawniczych w Polsce, były prezes Trybunału Konstytucyjnego i rzecznik praw obywatelskich prof. Andrzej Zoll, analizując działania partii obecnie rządzącej, określił je jako „pełzający zamach na Konstytucję” oraz stwierdził, że „zaczynamy się zbliżać bardzo szybkim krokiem do systemu autorytarnego". Jedno jest pewne: bez względu na to, jak daleko obecna większość parlamentarna zdoła posunąć się na drodze niszczenia $\mathrm{w}$ Polsce podstaw demokratycznego państwa prawnego (rule of law), a w szczególności zasad trójpodziału władzy, niezależności sądów i niezawisłości sędziów, dla polskich prawników, którym zasady te są bliskie w pełni ziściło się przekleństwo „obyś żył w ciekawych czasach”.

Dariusz Mazur

Sędzia Sqdu Okręowego w Krakowie

dariusz.mazur@krakow.so.gov.pl

Waldemar Żurek

Sędzia Sqdu Okręgowego w Krakowie

waldemar.zurek@krakow.so.gov.pl 


\title{
THE JUDICIARY IN POLAND AT THE THRESHOLD OF 2017: CHALLENGES AND THREATS
}

\author{
Sum mary
}

The paper examines the first year of the Law and Justice Party's (Prawo i Sprawiedliwość) government which has implemented many changes in the system of justice in Poland by virtue of ordinary acts of parliament. Some of the measures taken by the government were aimed at increasing the competences of the executive powers over the judiciary by a reference to a preferential interpretation of the existing regulations, whereas others focused on the implementation of changes in the legislative. While there are no doubts that the system of justice needs modifications to increase the efficiency of courts, most changes currently implemented or planned to be implemented raise serious concerns among the judges. In 2016, the ruling party aimed first at subordinating or paralysing the work of the Constitutional Tribunal; later it went on to implement changes in the Prosecutor's Office with a view of making it politically dependent, increasing at the same time the competences of the executive, by, among other things, new legislative solutions. In January 2017 a draft of an act of parliament to amend the National Chamber of the Judiciary was announced. If implemented it will bring about fundamental and unconstitutional changes to the political system of the Republic of Poland and will politicise the Council, depriving self-governing judiciary bodies of the actual say in the process of identifying candidates for judicial appointments. 